\title{
Development and evaluation of an enzyme-linked immunosorbent assay (ELISA), using chlamydial group antigen, to detect antibodies to Chlamydia trachomatis
}

\author{
RT EVANS, D TAYLOR-ROBINSON \\ From the Sexually Transmitted Diseases Research Group, Division of Communicable Diseases, MRC Clinical \\ Research Centre, Watford Road, Harrow, Middlesex HA1 3UJ
}

SUMMARY Chlamydial group antigen was extracted from Chlamydia trachomatis strain $\mathrm{SA}_{2}(\mathrm{f})$ and used as the antigen for an ELISA. The assay was reproducible since chlamydial antibody titres differed by no more than twofold when sera were tested on up to eight occasions. In tests on sera from 75 patients attending venereal disease or rheumatology clinics, the results of the ELISA and of a microimmunofluorescence (MIF) technique were similar for 61 of the sera, that is an $81 \%$ agreement. However, the ELISA was a little more sensitive than the MIF technique and at least tenfold more sensitive than the complement fixation procedure. Chlamydial IgG antibody at a titre of $1 / \geqslant 16$ was detected by the ELISA in $6 \%$ of children's sera, in $20 \%$ of sera from adult patients attending hospital with non-venereal diseases and in $85 \%$ of sera from persons attending venereal disease or rheumatology clinics. IgM and IgG antibodies were detected also by the ELISA in the sera of chimpanzees and marmosets which had been infected genitally with $C$ trachomatis and, in general, the titres were greater than those recorded by the MIF test. The value of the ELISA in comparison with the MIF test is discussed.

Chlamydiae cause ocular, respiratory, and genital diseases of man and animals. Thus, Chlamydia trachomatis is responsible for trachoma, neonatal pneumonia, lymphogranuloma venereum (LGV) and other oculogenital diseases. Chlamydia psittaci is responsible for the psittacosis/ornithosis group of diseases. Chlamydial infection may be demonstrated either by isolating the organisms in cell culture or, less often, by serological means-although in neonatal pneumonia, LGV, and psittacosis it is usual to make the diagnosis serologically.

The technique used commonly for serodiagnosis is complement fixation. It is, however, not as sensitive as the microimmunofluorescence (MIF) test, ' but this requires fluorescence microscopy with its attendant disadvantages of subjective analysis and the need for skilled operators. The radioisotope-precipitation test $^{2}$ has been used for detection of antichlamydial antibodies, although the specialised nature of the equipment required puts it beyond the resources of a routine laboratory.

Accepted for publication 22 February 1982
In recent years the enzyme-linked immunosorbent assay (ELISA) ${ }^{3}$ has been used to detect antibody to a wide range of microbial antigens. ${ }^{4}$ The assay is claimed to be extremely sensitive, and the results can be read either subjectively by seeking colour changes or objectively by determining absorbance values. Lewis et $^{a^{5}}$ developed an ELISA for $C$ psittaci which involved actively fixing chlamydial elementary bodies to the wells of microtitre plates. We found this method to be of variable reproducibility and have developed an ELISA for $C$ trachomatis, based on passively adsorbed extracted chlamydial group antigen, which is reproducible and sensitive and may be useful diagnostically and epidemiologically.

\section{Material and methods}

ANTIGEN PREPARATION

The yolk sacs of 100 seven-day-old fertile hens' eggs were each inoculated with $0.2 \mathrm{ml}$ of a $1 / 10$ dilution of a suspension containing $10^{10}$ inclusion-forming units of chlamydial strain $\mathrm{SA}_{2}(\mathrm{f}) / \mathrm{ml}$. The eggs were incubated at $37^{\circ} \mathrm{C}$ and when the embryos of half of 
them died the remainder were put at $4^{\circ} \mathrm{C}$ to kill the embryos. Then the yolk sacs of all 100 eggs were harvested, an equal volume of PBS " $A$ " was added and the sacs homogenised in an MSE "Atomix" blender for $3 \mathrm{~min}$. The homogenate was centrifuged at $500 \mathrm{~g}$ for $10 \mathrm{~min}$ and the supernatant fluid at 12000 $g$ for $1 \mathrm{~h}$. The resulting supernatant fluid was layered on a 20\% Urografin (Schering) gradient and centrifuged at $25000 \mathrm{~g}$ for $2 \mathrm{~h}$. The pellet was resuspended in PBS " $A$ " which was layered on a $32 \%$ Urografin gradient and centrifuged as before. The pellet was resuspended in $20 \mathrm{ml}$ of PBS " $A$ " to which $2.5 \mathrm{ml}$ of $1 \%$ sodium deoxycholate was added and the mixture incubated, with shaking, at $45^{\circ} \mathrm{C}$ for $4 \mathrm{~h}$. Finally, the mixture was centrifuged at $30000 \mathrm{~g}$ for $20 \mathrm{~min}$ and the supernatant fluid constituted the antigen, the required concentration for assays being established by a chequerboard titration.

Complement-fixation (CF) test antigen, extracted from the ovine enzootic abortion strain of $C$ psittaci, and supplied by the Public Health Laboratory Service (PHLS) (Colindale, London), was used in an ELISA in comparison with the antigen described above.

\section{SERA}

Sera were obtained from adult patients attending venereal disease clinics with non-gonococcal urethritis, and rheumatology clinics with suspected Reiter's disease. Sera from 132 children, ranging in age from one week to $12 \mathrm{yr}$, were obtained from the Clinical Chemistry Department of Northwick Park Hospital. All these sera were frozen at $-20^{\circ} \mathrm{C}$ before being tested. Unfrozen sera from 300 patients with complaints other than venereal disease were obtained from various pathology departments of Northwick Park Hospital. In addition, sera from male chimpanzees $^{6}$ and female marmosets ${ }^{7}$ which had been inoculated genitally with strains of $C$ trachomatis isolated from the human genital tract were tested. Sera from uninoculated animals were tested also. The sera from all these animals were kept at $-20^{\circ} \mathrm{C}$ before being tested.

\section{ELISA TECHNIQUE}

A $100 \mu$ l volume of antigen, diluted to the required concentration in carbonate-bicarbonate buffer $(\mathrm{pH}$ $9 \cdot 6$ ), was added to each well of M29A Microelisa plates (Dynatech Laboratories). The plates were kept at $4^{\circ} \mathrm{C}$ overnight and then washed four times during a 10 min period with PBS " $A$ " $/ 0.05 \%$ Tween 20 . Test sera were diluted in PBS/Tween and $100 \mu l$ added to appropriate wells, after which the plates were kept at $4^{\circ} \mathrm{C}$ for $3 \mathrm{~h}$ and then washed as before. A $100 \mathrm{ml}$ volume of alkaline phosphatase conjugated to antihuman immunoglobulin (Miles Labs or Don Whitley Scientific) was then added to each well, the appropriate dilution having been determined previously by a chequerboard assay. The plates were kept at $4^{\circ} \mathrm{C}$ for $3 \mathrm{~h}$ and washed as described previously. The substrate was prepared by adding a $5 \mathrm{mg}$ tablet of Sigma 104 PNPP to $5 \mathrm{ml}$ of ELISA Substrate Buffer (Don Whitley) and $100 \mu$ l were added to each well. The plates were left at room temperature for $30 \mathrm{~min}$ after which the results were read, both visually and on a Titertek "Multiskan" microelisa reader at $405 \mathrm{~nm}$.

\section{CHLAMYDIAL ANTIBODY TITRE}

DETERMINATION

Originally, all sera were diluted from $1 / 8$ to $1 / 1024$ and absorbance values were compared with those for sera known to be antibody negative by the MIF test. Any serum having an absorbance value greater than the mean absorbance value of the negative sera $+2 \cdot 5$ standard deviations was regarded as antibody positive.

Latterly, we used a mathematical method ${ }^{8}$ to determine the antibody titre. This determines the intercept of the straight line formed by taking the absorbance values (mean +2.5 standard deviations) for three dilutions of negative sera and the curve fitted to the absorbance values for the same dilutions of test sera. By applying the indicated formula, the antibody titre may be obtained:

$$
\text { Intercept } Z=2+\frac{2}{B}\left(E-\sqrt{E^{2}-2 B(Y 2-D)}\right.
$$

Titre $\quad \mathrm{X}=\mathrm{D} 1 . \mathrm{N}^{(\mathrm{Z}-1)}$

where $\mathrm{B}=\mathrm{Y} 1-2 \mathrm{Y} 2+\mathrm{Y} 3$

$$
\begin{aligned}
& D=\frac{(S 1+S 2 \times S 3)}{3} \\
& E=\frac{(S 3-S 1)-(Y 3-Y 1)}{2} .
\end{aligned}
$$

Y1, Y2, Y3 are absorbance values of test sera at dilutions $1,2,3$.

S1, S2, S3 are absorbance values (mean +2.5 standard deviations) of negative sera at the same dilutions.

D1 is the original dilution.

$\mathrm{N}$ is the dilution factor (i.e. if dilutions are 1/16,1/64 and $1 / 256$ the dilution factor is 4 ).

The results were calculated on a DEC-2060 computer or an NEC microcomputer using programs written in BASIC.

\section{COMPLEMENT-FIXATION TEST}

Complement-fixation (CF) tests were performed using the method of Bradstreet and Taylor. ${ }^{9}$ The antigen used in the test was that supplied by the PHLS. 
MICROIMMUNOFLUORESCENCE TEST

Microimmunofluorescence (MIF) tests were performed using the method of Thomas et al. ${ }^{10} \mathrm{C}$ trachomatis serotypes D-K were used as antigens, and a serotype $B$ additionally in the tests on human sera.

AGAR-GEL DOUBLE DIFFUSION TEST

Glass microscope slides were covered with $0.5 \mathrm{ml}$ of $0.6 \%$ melted agarose (l'Industrie Biologique Française, Gennevilliers, France) in phosphate

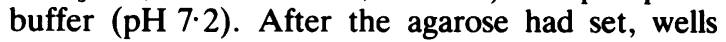
were made with a five-hole template. Human, or mouse, antichlamydial serum or normal human or mouse serum was added to the centre well. The outer wells were filled with either the extracted antigen, the PHLS CF antigen or normal yolk sac which had been subjected to a Urografin gradient and deoxycholate extraction. The slides were kept moist at room temperature for $40 \mathrm{~h}$ after which they were examined for precipitin lines.

\section{Results}

IDENTITY OF EXTRACTED ANTIGEN FOR THE ELISA

When either the mouse or human antichlamydial serum was in the centre well two precipitin lines formed between that well and those containing either the extracted antigen or the PHLS CF antigen. Furthermore, these lines fused in a reaction of identity when either of the two antigens were in adjacent wells. No precipitin lines were produced by an extract of normal yolk sac, nor by normal serum of either mouse or human species. These results indicated the specificity and chlamydial nature of the extracted antigen used in the ELISA.

\section{ESTABLISHING ABSORBANCE VALUES AND CHLAMYDIAL ANTIBODY TITRES OF HUMAN SERA}

\section{Negative values}

The 132 children's sera were tested in the ELISA and the absorbance values were recorded. Eight sera produced a distinct colour change at a dilution of $1 / 16$ or greater and they were excluded from the determination of negative values. All the remaining sera at a dilution of $1 / 16$ had an absorbance value below $0 \cdot 3$. The mean absorbance value of these sera, at a $1 / 16$ dilution, plus 2.5 standard deviations was $0 \cdot 348$. Thus, a serum producing a value less than this was regarded as not containing chlamydial antibody. The negative sera were also diluted further in three fourfold steps so that the titre could be estimated by the mathematical model: the absorbance values for dilutions of $1 / 64,1 / 256$ and $1 / 1024$ were $0 \cdot 329,0 \cdot 3$ and $0 \cdot 281$, respectively.

\section{Positive values}

Any serum, at a 1/16 dilution, was regarded as "positive" for chlamydial antibody if the absorbance value was greater than $0 \cdot 348$. In cases where the absorbance value for the test serum was high, the mathematical formula would not allow the curve for the test serum to intercept the plotted line for the negative serum, so that the result would be reported as " $1 / \geqslant 256$ ". By establishing a fourth negative value $(1 / 1024)$, and by using an initial dilution of $1 / 64$ instead of $1 / 16$, the calculation could be repeated and the titre determined accurately.

\section{COMPARISON OF METHODS OF}

ESTABLISHING THE CHLAMYDIAL

ANTIBODY TITRE BY THE ELISA

Chlamydial antibody titres were estimated after (i) a subjective determination of colour change, (ii) an objective determination of absorbance values by the microelisa reader, and (iii) subjecting the absorbance values to the mathematical model. The results obtained by the three methods correlated closely. If a serum was "positive" at a particular dilution by the microelisa reader, it was positive also by subjective reading. The results obtained by the mathematical model were similar to those recorded by the microelisa reader except that the former was more exact. Thus, in some cases where the antibody titre recorded by the microelisa reader was, for example, $1 />16$ and $1 /<64$, that obtained from the mathematical model was, for example, $1 / 48$.

\section{REPRODUCIBILITY OF THE ELISA}

The chlamydial antibody titres for seven human sera were determined by making serial doubling dilutions and for four sera by using the mathematical model. The titre of a serum, tested on up to eight occasions, differed by no more than twofold, irrespective of the method of its determination.

\section{TESTS ON SERA FROM PATIENTS \\ ATTENDING VENEREAL DISEASE AND \\ RHEUMATOLOGY CLINICS}

Comparison of chlamydial antibody titres determined by MIF and the ELISA

Seventy-five sera which had been tested previously by the MIF test were tested by the ELISA. There was an exact correlation between the results of the two types of test for 61 of the sera, that is an $81 \%$ agreement (Table 1). However, the ELISA was more sensitive than the MIF test because chlamydial antibody was detected in 11 sera by the ELISA but not by MIF. 
Table 1 Comparison of the results of testing sera by the ELISA and MIF

\begin{tabular}{|c|c|}
\hline Result of test & $\begin{array}{l}\text { Proportion of sera with } \\
\text { indicated result }\end{array}$ \\
\hline $\begin{array}{l}\text { Negative by both tests (titre } 1 /<16 \\
\text { Positive by both tests ( titre } 1 / \geqslant 16\end{array}$ & $81 \%$ agreement \\
\hline $\begin{array}{l}\text { MIF positive-ELISA negative } \\
\text { ELISA positive-MIF negative }\end{array}$ & $19 \%$ disagreement \\
\hline
\end{tabular}

${ }^{*}$ Individual results (reciprocal titres) MIF/ELISA: 16/15, 32/14, 32/15.

+ Individual results (reciprocal titres) ELISA/MIF: $18 /<8,23 /<8,23 /<8,24 /<8,24 / 8,26 /<8,42 /<8,53 / 8,127 / 8,312 / 8,500 /<8$.

Moreover, the antibody titre determined by the ELISA was at least twofold greater than by MIF in $53 \%$ of the sera, whereas the reverse was seen in only $20 \%$ of the sera.

Sequential sera from six patients were tested (Table 2). The results on sera from four patients by the ELISA were comparable with those by MIF. There were, however, two patients whose sera behaved differently in the two tests. The titres of antibody in the sera of one patient (Ma) were consistently high as measured by the ELISA but low by MIF, whereas the reverse was seen in the case of another patient $(\mathrm{Ke})$.

Table 2 Comparison of antibody titres in sequential sera tested by the ELISA and MIF

\begin{tabular}{|c|c|c|}
\hline \multirow[t]{2}{*}{ Patient } & \multicolumn{2}{|c|}{ Antibody titres (reciprocal) by } \\
\hline & $\overline{E L I S A}$ & $M I F$ \\
\hline $\mathrm{Ca}$ & 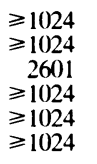 & $\begin{array}{r}512 \\
2048 \\
2048 \\
1024 \\
2048 \\
256\end{array}$ \\
\hline $\mathrm{Ma}$ & $\begin{array}{l}\geqslant 1024 \\
\geqslant 1024 \\
\geqslant 1(024\end{array}$ & $\begin{array}{r}256 \\
16 \\
16\end{array}$ \\
\hline $\mathrm{Ke}$ & $\begin{array}{r}686 \\
212 \\
39 \\
24 \\
23 \\
15 \\
33 \\
\geqslant 1024\end{array}$ & $\begin{array}{r}128 \\
256 \\
512 \\
1024 \\
1024 \\
1024 \\
1024 \\
256\end{array}$ \\
\hline J & $\begin{array}{r}10 \\
0 \\
3 \\
6\end{array}$ & $\begin{array}{l}0 \\
0 \\
0 \\
0\end{array}$ \\
\hline $\mathrm{Mc}$ & $\begin{array}{r}386 \\
333 \\
60 \\
24\end{array}$ & $\begin{array}{r}128 \\
128 \\
64 \\
0\end{array}$ \\
\hline $\mathrm{Cl}$ & $\begin{array}{l}6 \\
6\end{array}$ & $\begin{array}{l}0 \\
0\end{array}$ \\
\hline
\end{tabular}

Comparison of chlamydial antibody titres determined by the ELISA and CF

Twelve of the 75 sera tested previously were examined again by the ELISA using the extracted antigen and also the CF antigen supplied by the PHLS. In addition, the sera were tested by CF using the PHLS antigen. The results, presented in Table 3, show that the chlamydial antibody titres obtained with the two different antigens in the ELISA tests were comparable and were at least tenfold greater than those measured in the $\mathrm{CF}$ test.

TESTS ON SERA FROM A GENERAL

HOSPITAL POPULATION

Sera from 300 adult patients attending hospital for reasons not associated with venereally acquired diseases were tested by the ELISA. The results, including those of tests on 132 sera from children, are shown in Table 4. As mentioned previously, $8(6 \%)$ of the children's sera contained antibody at a titre of $1 / \geqslant 16$. In comparison, $59(20 \%)$ of the adult sera contained antibody, but only $9(3 \%)$ contained antibody at a titre of $1 / \geqslant 256$. This is in contrast to the presence of antibody (titre of $1 / \geqslant 16)$ in $64(85 \%)$ of the sera from 75 patients attending venereal disease or rheumatology clinics.

Table 3 Comparison of antibody titres measured by the ELISA and CF

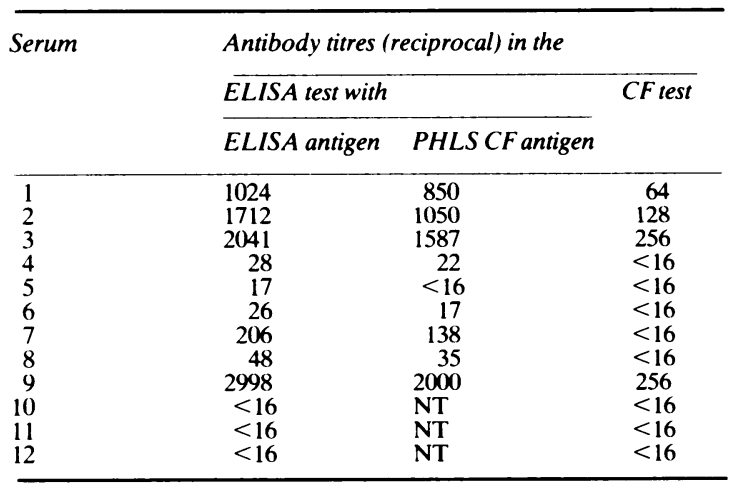

NT $=$ not tested. 
Table 4 Antibody titres determined by the ELISA in sera from non-venereal disease patients

\begin{tabular}{lllll}
\hline $\begin{array}{l}\text { Serum } \\
\text { from }\end{array}$ & $\begin{array}{l}\text { No of } \\
\text { sera } \\
\text { tested }\end{array}$ & \multicolumn{3}{l}{$\begin{array}{l}\text { No(\%) of patients with antibody titre* } \\
\text { (reciprocal) of }\end{array}$} \\
\cline { 3 - 5 } & & $16-63$ & $64-256$ & $>256$ \\
\hline Children & 132 & $4(3 \%)$ & 0 & $4(3 \%)$ \\
Adults & 300 & $38(12 \cdot 6 \%)$ & $12(4 \%)$ & $9(3 \%)$ \\
\hline
\end{tabular}

${ }^{*}$ Determined by the mathematical model.

TESTS ON SERA FROM ANIMALS

INOCULATED GENITALLY

WITH C TRACHOMATIS

\section{Chimpanzee sera}

Sera from five male chimpanzees which had been inoculated intraurethrally with chlamydiae were available. They had been examined previously by the MIF test and were tested by the ELISA (Table 5). Seroconversion was demonstrated in three of the five animals by both methods. One animal (No 8) had no antibody response demonstrable by either method, and another (No 338) had IgM antibody at a titre of $1 / 16$ demonstrable by MIF, but no significant titre shown by the ELISA.

A sixth chimpanzee (No 27), which had been inoculated with medium only, did not have preexisting IgG or IgM antibodies, or develop them, as judged by MIF. However, there was a low titre of pre-existing IgG antibody which did not increase significantly, as measured by the ELISA.

\section{Marmoset sera}

Three of four female marmosets which had been inoculated intravaginally with chlamydiae exhibited seroconversion by both MIF and the ELISA (Table 6), although higher titres of both IgM and IgG antibodies were recorded by the latter procedure. Both tests failed to demonstrate chlamydial antibody, of either class, in sera from the fourth inoculated animal (No 84) and no antibody was detected by either test in sera from marmoset No 67 which had been inoculated with medium only.

\section{Discussion}

Originally, we attempted to modify the ELISA described for $C$ psittaci by Lewis $e t$ al, ${ }^{5}$ by using, as antigen, chlamydial strain $\mathrm{SA}_{2}$ (f) which has been shown to crossreact with the majority of $C$ trachomatis serotypes. ${ }^{10}$ However, we found that the test behaved in an unpredictable manner, whether we used alkaline-phosphatase-conjugated antiserum or peroxidase-conjugated antiserum. The system we developed eventually is reproducible and the results are easy to interpret visually and by machine provided alkaline-phosphatase conjugates are used. We had hoped to use peroxidase conjugates because the more intense colours they produce would have been easier to interpret visually. However, the "background" coloration we encountered made determination of end-points difficult. This was true irrespective of whether the substrate used was O-phenylenediamine, dinitrobenzidine, 5-amino-salicylic acid or 2,2azino-di(3-ethylbenzylthiazoline sulphonic acid). The peroxidase conjugates we used originally were produced by glutaraldehyde linkage. " Although it has been suggested that periodate-linked conjugates might give lower "background" absorbance values, ${ }^{12}$ we were unable to show this and continued to use alkaline-phosphatase conjugates.

Table 5 Antibody titres determined by the ELISA and MIF in sera from chimpanzees

\begin{tabular}{|c|c|c|c|c|c|}
\hline \multirow{2}{*}{$\begin{array}{l}\text { Chimpanzee } \\
\text { No }\end{array}$} & \multirow{2}{*}{$\begin{array}{l}\text { Days after intraurethral } \\
\text { inoculation of chlamydiae }\end{array}$} & \multicolumn{2}{|c|}{ IgM antibody titre (reciprocal) by } & \multicolumn{2}{|c|}{ IgG antibody titre (reciprocal) by } \\
\hline & & ELISA & $M I F$ & $E L I S A$ & $M I F$ \\
\hline 8 & $\begin{array}{r}3 \\
47\end{array}$ & $\begin{array}{l}0 \\
0\end{array}$ & $\begin{array}{l}0 \\
0\end{array}$ & $\begin{array}{l}\mathbf{0} \\
0\end{array}$ & $\begin{array}{l}0 \\
0\end{array}$ \\
\hline $27^{*}$ & $\begin{array}{r}0 \\
47\end{array}$ & $\begin{array}{l}0 \\
0\end{array}$ & $\begin{array}{l}0 \\
0\end{array}$ & $\begin{array}{l}28 \\
43\end{array}$ & $\begin{array}{l}0 \\
0\end{array}$ \\
\hline 34 & $\begin{array}{r}0 \\
42\end{array}$ & $\begin{array}{r}0 \\
160\end{array}$ & $\begin{array}{r}0 \\
\geqslant 256\end{array}$ & $\begin{array}{r}0 \\
288\end{array}$ & $\begin{array}{r}0 \\
64\end{array}$ \\
\hline 37 & $\begin{array}{r}0 \\
41\end{array}$ & $\begin{array}{l}0 \\
4\end{array}$ & $\begin{array}{l}0 \\
8\end{array}$ & $\begin{array}{r}0 \\
\geqslant 256\end{array}$ & $\begin{array}{r}0 \\
32\end{array}$ \\
\hline 38 & $\begin{array}{r}0 \\
41\end{array}$ & $\begin{array}{r}0 \\
10\end{array}$ & $\begin{array}{l}0 \\
8\end{array}$ & $\begin{array}{l}0 \\
7\end{array}$ & $\begin{array}{r}0 \\
16\end{array}$ \\
\hline 338 & $\begin{array}{r}0 \\
13 \\
41\end{array}$ & $\begin{array}{l}0 \\
8 \\
7\end{array}$ & $\begin{array}{r}0 \\
4 \\
16\end{array}$ & $\begin{array}{l}0 \\
0 \\
5\end{array}$ & $\begin{array}{l}\mathbf{0} \\
0 \\
0\end{array}$ \\
\hline
\end{tabular}

${ }^{*}$ Not given chlamydiae. 
Table 6 Antibody titres determined by the ELISA and MIF in sera from marmosets

\begin{tabular}{|c|c|c|c|c|c|}
\hline \multirow{2}{*}{$\begin{array}{l}\text { Marmoset } \\
\text { No }\end{array}$} & \multirow{2}{*}{$\begin{array}{l}\text { Days after intravaginal } \\
\text { inoculation of chlamydiae }\end{array}$} & \multicolumn{2}{|c|}{ IgM antibody titre by } & \multicolumn{2}{|c|}{ IgG antibody titre by } \\
\hline & & $E L I S A$ & MIF & $E L I S A$ & $M I F$ \\
\hline 52 & $\begin{array}{r}0 \\
12 \\
27 \\
42 \\
89\end{array}$ & $\begin{array}{r}2 \\
3 \\
33 \\
59 \\
6\end{array}$ & $\begin{array}{l}0 \\
4 \\
4 \\
4 \\
4\end{array}$ & $\begin{array}{r}0 \\
0 \\
0 \\
7 \\
\geqslant 256\end{array}$ & $\begin{array}{r}0 \\
2 \\
16 \\
32 \\
16\end{array}$ \\
\hline $67^{*}$ & $\begin{array}{r}0 \\
12 \\
27 \\
42 \\
89\end{array}$ & $\begin{array}{l}0 \\
0 \\
0 \\
0 \\
0\end{array}$ & $\begin{array}{l}0 \\
0 \\
0 \\
0 \\
0\end{array}$ & $\begin{array}{l}0 \\
0 \\
0 \\
0 \\
0\end{array}$ & $\begin{array}{l}0 \\
0 \\
0 \\
0 \\
0\end{array}$ \\
\hline 79 & $\begin{array}{r}0 \\
12 \\
27 \\
42 \\
89\end{array}$ & $\begin{array}{c}0 \\
\text { NT } \\
9 \\
29 \\
6\end{array}$ & $\begin{array}{l}0 \\
4 \\
0 \\
0 \\
2\end{array}$ & $\begin{array}{r}0 \\
0 \\
0 \\
22 \\
\geqslant 256\end{array}$ & $\begin{array}{l}0 \\
0 \\
8 \\
8 \\
8\end{array}$ \\
\hline 84 & $\begin{array}{r}0 \\
12 \\
27 \\
42 \\
89\end{array}$ & $\begin{array}{l}0 \\
0 \\
0 \\
0 \\
0\end{array}$ & $\begin{array}{l}0 \\
0 \\
0 \\
0 \\
0\end{array}$ & $\begin{array}{l}0 \\
0 \\
0 \\
0 \\
3\end{array}$ & $\begin{array}{l}0 \\
4 \\
4 \\
0 \\
0\end{array}$ \\
\hline 87 & $\begin{array}{r}0 \\
12 \\
27 \\
42 \\
89\end{array}$ & $\begin{array}{r}0 \\
11 \\
12 \\
6 \\
0\end{array}$ & $\begin{array}{l}0 \\
4 \\
2 \\
0 \\
0\end{array}$ & $\begin{array}{r}0 \\
0 \\
0 \\
214 \\
1274\end{array}$ & $\begin{array}{l}2 \\
8 \\
8 \\
8 \\
8\end{array}$ \\
\hline
\end{tabular}

*Not given chlamydiae.

NT $=$ Not tested.

Determination of the antibody titre in the ELISA was a problem. There appears to be no standard method of doing this. Some workers have not stated their method whereas others regard the well which contains fluid noticeably darker than the corresponding control as the end-point. In addition, results are presented as ratios of positive to negative absorbance values and also as values greater than an arbitrary fixed value. We decided to use a method employed by several other workers, regarding a serum as "positive' if the absorbance value was equal to or greater than the mean of the absorbance values of several negative sera, at a given dilution, plus 2.5 standard deviations. The mathematical method of determining the antibody titre has several advantages. It provides a precise titre which can be determined by using only three or four dilutions of serum. This, in turn, enables a greater number of assays to be performed in each microtitre plate, with an attendant saving in cost.

The sensitivity of the ELISA for detecting chlamydial antibody was greater than that of the MIF technique and considerably greater than that of the CF test. The specificity of the ELISA may be gauged, to some extent, by the results obtained from examining sera from different groups of persons. Antibody was found infrequently in children, a little more frequently in adults attending a general hospital and was present in almost all the sera of persons attending a venereal disease clinic. These results are consistent with the distrubution of $C$ trachomatis in the population. However, because the ELISA detects antibody directed against the chlamydial group antigen (vide infra), there is no reason to believe that antibody to $C$ psittaci would not be detected by the extracted $\mathrm{SA}_{2}(\mathrm{f})$ antigen. The apparent specificity of the ELISA is, therefore, probably a measure of the relatively infrequent occurrence of infection by $C$ psittaci.

The results obtained by the ELISA correlated closely with those obtained by MIF in tests on sera from chimpanzees and marmosets that had been infected with $C$ trachomatis. There was good agreement also in comparative tests on human sera. However, with these, the results obtained by the ELISA and by MIF did not always correlate. An explanation for this could be that the MIF technique measures antibody to various antigens on the surface of chlamydiae, whereas the ELISA described here detects antibody only to the group antigen which may be expressed to a lesser extent on the organism surface.

The ELISA we have developed is sensitive, reproducible, capable of being automated and the 
antibody titres may be determined precisely. In its present form it is undoubtedly an alternative to the CF test. Many laboratories are now equipped to detect antibody against other micro-organisms by ELISA and the technique we describe would be complementary to these assays. Production of antigen is simple and it can be stored in aliquots at $-20^{\circ} \mathrm{C}$ until required. The ELISA results obtained with the PHLS CF antigen indicate that it is a suitable alternative to the antigen we prepared. However, whether the ELISA could be used as an alternative to the MIF technique is open to question. The latter has the advantage of detecting antibodies to the whole range of chlamydial serotypes. Further development of the ELISA is likely to provide it with this attribute.

We thank Dr B Thomas for supplying the sera for which MIF test results were available, various pathology departments of Northwick Park Hospital for providing the other human sera, and Dr AP Johnson for the marmoset sera. Complementfixation tests were performed in the Microbiology Department of Northwick Park Hospital.

\section{References}

' Philip RN, Casper EA, Gordon FB, Quan AL. Fluorescent antibody responses to chlamydial infections in patients with lymphogranuloma venereum and urethritis. J Immunol 1974; 112:2126-34.

2 Gerloff RK, Watson RO. The radioisotope precipitation test for psittacosis group antibodies. Am J Ophthalmol 1967;63: 1492-8.
${ }^{3}$ Engvall E, Perlmann P. Enzyme-linked immunosorbent assay (ELISA). III Quantitation of specific antibodies by enzymelabelled anti-immunoglobulins in antigen coated tubes. $J$ Immunol 1972;109:129-35.

4 Sever JT, Madden DL, eds. Enzyme-linked immunosorbent assay (ELISA) for infectious agents. J Infect Dis 1977;136(suppl): 257-340.

5 Lewis VJ, Thacker WL, Mitchell SH. Enzyme-linked immunosorbent assay for chlamydial antibodies. J Clin Microbiol 1977;6:507-10.

- Taylor-Robinson D, Purcell RH, London WT, Sly DL. Thomas BJ, Evans RT. Microbiological, serological, and histopathological features of experimental Chlamydia trachomatis urethritis in chimpanzees. BrJ Vener Dis 1981;57:36-40.

7 Johnson AP, Hetherington CM, Osborn MF, Thomas BJ, TaylorRobinson D. Experimental infection of the marmoset genital tract with Chlamydia trachomatis. Br J Exp Pathol 1980; 61:291-5.

* Nicholson KG, Prestage H. Enzyme-linked immunosorbent assay: a rapid reproducible test for the measurement of rabies antibody. J Med Virol 1982;9:43-9.

${ }^{9}$ Bradstreet CM, Taylor CE. Technique of complement-fixation test applicable to the diagnosis of virus diseases. Monthly Bulletin of the Ministry of Health (London) 1962;21:96-104.

10 Thomas BJ, Reeve P, Oriel JD. Simplified serological test for antibodies to Chlamydia trachomatis. J Clin Microbiol 1976; 4:6-10.

"Avrameas S. Détection d'anticorps et d'antigènes à l'aide d'enzymes. Bull Soc Chim Biol 1968;50:1169.

12 Nakane PK, Kawaoi A. Peroxidase-labelled antibody. A new method of conjugation. J Histochem Cytochem 1974;22: 1084-91.

Requests for reprints to: Dr D Taylor-Robinson, Division of Communicable Diseases, Clinical Research Centre, Watford Road, Harrow, Middlesex HA1 3UJ, England 